\title{
COPENHAGEN RADIOCARBON DATES V
}

\author{
HENRIK TAUBER
}

Carbon-14 Dating Laboratory,

Department of Natural Sciences, National Museum, Copenhagen

The following list includes samples dated in the period 1956-1961.

Age calculations are based on a contemporary value equal to $95 \%$ of the activity of the NBS oxalic-acid standard, and on a half life for $\mathrm{C}^{14}$ of 5568 $\pm 30 \mathrm{yr}$.

Results are expressed in years before 1950; ages in the B.C.-A.D. scales are given in parentheses in the sample descriptions. Errors quoted include the standard deviation of the count rates of the unknown sample, of the contemporary value, and of the background. Calculated errors smaller than $100 \mathrm{yr}$ have been increased by rounding to that figure as a minimum.

The samples were selected by a committee of archaeologists and geologists consisting of Therkel Mathiassen, Helge Larsen, and J. Troels-Smith, National Museum, Copenhagen, and Sigurd Hansen and Johs. Iversen, Geological Survey of Denmark. Sample descriptions have been prepared in collaboration with the collectors and submitters. Chemical preparation was done by Elisabeth Østbjerg, xylotomic determinations by E. Tellerup.

\section{SAMPLE DESCRIPTIONS}

I. GEOLOGIC AND POLLEN-DATED SAMPLES

\section{A. Denmark}

\section{Great Belt series, postglacial submergence}

Samples from two borings (nos. 96 and 153) through former fresh water beds, made in the Great Belt, Denmark, at water depths of 28 and $23 \mathrm{~m}$ respectively. Geographic position of borings: no. 96 at $56^{\circ} 23^{\prime} \mathrm{N}$ Lat, $10^{\circ} 56^{\prime} \mathrm{E}$ Long, and no. 153 at $55^{\circ} 47^{\prime} \mathrm{N}$ Lat, $10^{\circ} 55^{\prime} \mathrm{E}$ Long. The cores $(2.4$ and $2.2 \mathrm{~m}$ respectively) were investigated in order to date the postglacial submergence of the Great Belt. By pollen analysis, submergence is demonstrated to have spanned exactly the same time interval at the two localities; i.e. from late Zone-V time to early Zone-VII time. The dated samples represent the beginning of the submergence. Coll. 1954 and 1957 and subm. by Harald Krog, Geol. Survey of Denmark (Krog, 1960). Comment: samples are interpreted to reflect contemporaneous submergence of two localities in the Northern Great Belt, resulting either from eustatic rise in ocean level or from drainage water from the Ancylus Lake. The recent difference in level (ca. $4.5 \mathrm{~m}$ ) of the two fresh water beds is explained by differential isostatic uplift from the end of Zone-V time to the present.

K-593. Great Belt, D.G.U. $109 \quad 8510 \pm 150$

Non-calcareous peat from 2.4-m core, boring no. 96, top of Pollen Zone V. 
Position in core: $153-161 \mathrm{~cm}$. The peat deposit was covered by a layer of gyttja. (Age 6,560 \pm 150 в.c.)

K-592. Great Belt, D.G.U. 108

$\mathbf{8 5 9 0} \pm \mathbf{2 1 0}$

Non-calcareous peat from 2.4-m core, boring no. 96, top of Pollen Zone V. Position in core: 161-170 cm; i.e. immediately below K-593. (Age $6640 \pm$ 210 B.C.)

K-594. Great Belt, D.G.U. 110

$8660 \pm 150$

Peaty gyttja from 2.2-m core, boring no. 153, top of Pollen Zone V. Position in core: $205-216 \mathrm{~cm}$. Sample was covered by a layer of gyttja. (Age 6710 \pm 150 B.c.) Comment: sample contained mollusc shells, which were dissolved in acid before combustion.

K-595. Great Belt, D.G.U. 111

$8460 \pm 210$

Non-calcareous peaty gyttja from 2.2-m core, boring no. 153, top of Pollen Zone V. Position in core: $216-220 \mathrm{~cm}$; i.e. immediately below K-594. (Age $6510 \pm 210$ B.c.)

\section{B. Poland}

\section{Witow series, Bфlling oscillation}

Samples from a pollen-analysed Bølling section at Witow $\left(52^{\circ} 4^{\prime} \mathrm{N}\right.$ Lat, $19^{\circ} 11^{\prime}$ E Long), Province of Lodz, Poland. The Bølling deposits were covered by $240 \mathrm{~cm}$ of dune sand. All layers were non-calcareous. Coll. 1960 and subm. by Krystyna Wasylikowa, Univ. of Krakow, who also made the pollen analyses (Wasylikowa, in press). Comment: dates agree remarkably well with those from the very similar Bølling section at Usselo, Netherlands (Gro-925, 926, 927, 928, 933, 935, 947, 948, 1104, Groningen II ; K-541, 542, 543, 544, 545, $546,547,552,553$, Copenhagen IV). The duration of the Bølling oscillation was a few hundred years.

\section{K-706. Witow I/60}

$11,900 \pm 180$

Very sandy coarse detritus gyttja with layers of sand, 0.1 to $1 \mathrm{~cm}$ thick, 240 to $260 \mathrm{~cm}$ below surface. Represents transition from Bølling to Older Dryas, Pollen-Zones Ib/Ic. (Age $9950 \pm 180$ в.c.)

\section{K-708. Witow III $/ 60$ upper part $\quad 12,100 \pm 140$}

Sandy coarse detritus gyttja with some stratification, macrofossils: Potamogeton sp., Myriophyllum sp., Ceratophyllum demersum, Cyperaceae. 265 to $276 \mathrm{~cm}$ below surface. Represents Bølling oscillation, Pollen-Zone Ib. (Age $10,150 \pm 140$ B.c.)

K-707. Witow III/60 lower part $12,260 \pm 140$

Sandy coarse detritus gyttja with stratification, macrofossils: Potamogeton sp., Myriophyllum sp., Ceratophyllum demersum, Cyperaceae. 265 to $276 \mathrm{~cm}$ below surface. Represents Bølling oscillation (oldest part), Pollen-Zone Ib. (Age 10,310 \pm 140 в.c.) 
K-709. Witow $\mathrm{V} / 60$

$12,240 \pm 230$

Very sandy Amblystegiaceae-peat 280.5 to $285 \mathrm{~cm}$ below surface. Represents Oldest Dryas, Pollen-Zone Ia. Comment: sample was very small; this is reflected in the comparatively large error. (Age 10,290 \pm 230 B.c.)

\section{K-716. Wadowice}

Fossil wood (Picea sp.) from Wadowice ( $49^{\circ} 54^{\prime} \mathrm{N}$ Lat, $19^{\circ} 29^{\prime}$ E Long), Province of Krakow, Poland. From non-calcareous peat supposed to be of interglacial or interstadial age (Srodoń, in press). Coll. 1960 and subm. by A. Srodon, Univ. of Krakow.

\section{K-719. Zator 1}

Wood from a non-calcareous peat layer in a glacial deposit at Zator $\left(50^{\circ}\right.$ $0^{\prime} \mathrm{N}$ Lat, $19^{\circ} 25^{\prime} \mathrm{E}$ Long), Province of Krakow, Poland. Pollen analyses of the peat layer suggests an interstadial, possibly the Brørup (Srodon, in press). Coll. 1960 and subm. by A. Srodoń.

\section{ARCHAEOLOGIC SAMPLES}

\section{A. Alaska}

\section{Deering series, Ipiutak Culture}

Samples from Deering, a small Eskimo village $\left(66^{\circ} 4^{\prime} \mathrm{N}\right.$ Lat, $162^{\circ} 45^{\prime} \mathrm{W}$ Long), on S shore of Kotzebue Sound, Alaska. In 1949 remains of a large (9 by $6 \mathrm{~m}$ ) Ipiutak house was discovered on the landing field $\mathrm{W}$ of the village. The house had walls of very heavy, horizontal logs and five floor layers separated by layers of sterile gravel. It consisted of a main room and an anteroom. In both, as well as outside the house, were found many artifacts belonging to the Ipiutak culture. The find is remarkable because of the excellent state of preservation of organic materials like wood, birch bark, grass, skin, and hair (Larsen, 1951). Coll. 1949 and 1950 and subm. by Helge Larsen, Natl. Mus., Copenhagen. Comment: other Ipiutak dates of about the same age are given in Pennsylvania IV and Copenhagen III.

\section{K-532. Deering 1}

Birch bark from main room, field B 13, Ipiutak culture. (Age A.D. 570 $\pm 200)$.

\section{K-537. Deering 2}

$1290 \pm \mathbf{2 0 0}$ 200).

Dog faeces from anteroom, 3. layer, Ipiutak culture. (Age A.D. $660 \pm$

\section{B. Greenland}

\section{K-588. Itivnera, Sarqaq Culture $\quad 2960 \pm 110$}

Wood (Juniperus sp.) from Itivnera (64. $23^{\prime} \mathrm{N}$ Lat, $50^{\circ} 15^{\prime} \mathrm{W}$ Long), near bottom of Godthaab Fjord, W. Greenland. Site discovered 1955 by Jens Rosing and investigated in 1958 by Jens Rosing and Helge Larsen (Anonymous, 1959). Test diggings revealed several house remains containing artifacts of stone, bone, and antler which obviously belong to the Sarqaq culture. One 
house was excavated in 1958 and more in 1960. Coll. and subm. by Helge Larsen (Age $1010 \pm 110$ B.c.). Comment: sample material agrees with Juniperus communis saxatilis Pall., still growing at the locality. Juniperus may well be 100-200 $\mathrm{yr}$ old, and the site, therefore, may be slightly younger than the date. Other dates for Sarqaq culture in Greenland and Canada (Copenhagen IV and Pennsylvania IV) also agree.

\section{Denmark}

\section{K-599. Tømmerby Plow}

$$
\mathbf{3 3 0} \pm \mathbf{1 0 0}
$$

Wood (Quercus sp.) from a mold-board plow, presumably a wheel-plow, found in Tømmerby bog $\left(56^{\circ} 3^{\prime} \mathrm{N}\right.$ Lat, $9^{\circ} 31^{\prime} \mathrm{E}$ Long $)$, near Silkeborg, Jutland, some years before A.D. 1888. Previously dated by pollen analysis of the peat deposits to Pre-Roman Iron Age (Jessen, 1936). Desc. by Steensberg, 1936, and Glob, 1961; subm. by Axel Steensberg, Univ. of Copenhagen (Age A.D. $1620 \pm 100$ ). Comment: the plow had been treated with preservatives prior to dating, the last time in 1938. Agents used were aluminum sulfate, kerosene, and varnish. The plow was cut through and the interior proved to be well preserved with clearly visible year rings and a marked smell of kerosene. Sample material was taken from the inner part which contained the smallest amount of preservatives. Sample was ground and boiled several times with solutions of phosphoric acid and sodium hydroxide and with distilled water. After this treatment $40 \%$ of the sample was left in the form of a light, humicfree powder without any smell of kerosene. Half of the sample material was then treated with $72 \%$ sulfuric acid in order to dissolve and decompose cellulose and other carbohydrates (Olson and Broecker, 1958). By hydrolysis a precipitate of lignin was obtained; after washing and drying it consisted of a brownish powder with no smell. The other half of the sample was treated with an acid solution of sodium chlorite (Barghoorn, 1948). In this way a white precipitate of cellulose was left. This was dissolved in a solution of cuprammonioum hydroxide, the solution was filtered and cellulose reprecipitated as a white powder. The untreated sample material, the lignin, and the cellulose fractions were dated separately with the following results:

1. Untreated sample material

$$
\begin{array}{r}
1240 \pm 100 \\
370 \pm 100 \\
300 \pm 100
\end{array}
$$

2. Lignin fraction

3. Cellulose fraction

The final date is the average of the dates for the lignin and the cellulose fractions. The result for the untreated sample material corresponds to a content of $12 \%$ of $\mathrm{C}^{14}$-free kerosene. It was determined by $\mathrm{C}^{13} / \mathrm{C}^{12}$ measurements that no isotopic fractionation was introduced in the separation of the single fractions.

\section{K-598. Andbjerg Plow}

$$
430 \pm 100
$$

Wood (Fagus sp.) from a mold-board plow, presumably a wheel-plow, found in 1945 in Andbjerg bog $\left(56^{\circ} 3^{\prime} \mathrm{N}\right.$ Lat, $9^{\circ} 45^{\prime} \mathrm{E}$ Long), near Skanderborg, Jutland. Described by Glob, 1951; subm. by Axel Steensberg. (Age A.D. $1520 \pm 100$ ). Comment: the plow had been treated with preservatives such as 
aluminum sulfate, glycerine, and varnish prior to dating. Sample was taken from the interior, which looked to be unaffected by the chemical agents; it was treated like K-599. The lignin and the cellulose fractions were dated separately with the following results:
1. Lignin fraction
$400 \pm 100$
2. Cellulose fraction
$470 \pm 100$

The final date is the average of the dates for the lignin and the cellulose fractions. It was determined by $\mathrm{C}^{13} / \mathrm{C}^{12}$ measurements that no isotopic fractionation was introduced during separation.

\section{K-590. Hendriksmose Plow}

$\mathbf{2 3 0 0} \pm \mathbf{1 0 0}$

Wood (Quercus sp.) from an ard-plow of the bow-ard type found in 1957 in Hendriksmose bog $\left(56^{\circ} 26^{\prime} \mathrm{N}\right.$ Lat, $9^{\circ} 14^{\prime} \mathrm{E}$ Long $)$, near Viborg, Jutland. Described by Steensberg, in press; subm. by Axel Steensberg. (Age $350 \pm$ 100 в.с.). Comment: the plow had not been treated with preservatives.

\section{K-582. Draved, dwelling place no. 604}

$9060 \pm 130$

Charcoal from a dwelling place, no. 604, in the bog Draved Mose $\left(55^{\circ} 1^{\prime}\right.$ $\mathrm{N}$ Lat, $8^{\circ} 57^{\prime} \mathrm{E}$ Long), Løgumkloster, Jutland. The charcoal was found in a thin culture layer $(4-6 \mathrm{~cm}$ in thickness) together with primitive artifacts of Younger Klosterlund culture. The culture layer was covered by $1.5 \mathrm{~m}$ of peat, (Kapel, 1959). Coll. 1958 and subm. by Harald Krog. (Age $7110 \pm 130$ в.c.)

\section{Israel}

\section{K-620. Dead Sea tree}

$200 \pm 120$

Wood (Tamarix) from the Dead Sea (ca. $31^{\circ} 15^{\prime} \mathrm{N}$ Lat, $35^{\circ} 22^{\prime} \mathrm{E}$ Long), Israel. In the last 30 years the level of the Dead Sea has sunk ca. $6 \mathrm{~m}$, exposing a large number of tamarisk trees still rooted in place. Sample was from such a tree, covered by a salt crust, on the SW coast. Series of trees indicating various lake levels down to $50 \mathrm{~m}$ below the present level have been found. Coll. 1960 and subm. by D. Ashbel, Univ. of Jerusalem. (Age A.D. $1750 \pm 120)$.

\section{E. Polynesia}

\section{K-501. Poike Area, Easter Island 1}

$$
280 \pm \mathbf{1 0 0}
$$

Charcoal (Species 1) from ditch at Poike $\left(27^{\circ} 10^{\prime} \mathrm{S}\right.$ Lat, $109^{\circ} 20^{\prime} \mathrm{W}$ Long), Easter Island. Sample occurred in small pieces in burned earth in ditch fill $1 \mathrm{~m}$ below surface and $1.5 \mathrm{~m}$ above bottom of ditch (Smith, 1961). Date records a large fire in the ditch. Native tradition tells of such a fire during a war between two factions on the island. This event has been estimated to be ca. A.D. 1680 by Englert, 1948. Coll. 1955 by C. S. Smith, Univ. of Kansas, during the Norwegian Archaeol. Exped. to Easter Island; subm. by Thor Heyerdahl. (Age A.D. $1670 \pm 100$ ). Comment: it has not been possible to identify the species of wood; however, different species have been separated and numbered 1 to 11 for possible later identification. 
Charcoal (Species 7) found beneath $1 \mathrm{~m}$ of earth which was piled up when the ditch at Poike, Easter Island, described in K-501, was dug. Charcoal was mixed with sandy soil from the original surface before the earth from the ditch was placed over it. Dates the time prior to or the time when the ditch was being dug. Probably from Epoch 1 (Smith, 1961). Coll. 1955 by C. S. Smith; subm. by Thor Heyerdahl. (Age A.D. $380 \pm 100$ ).

K-507. Rano Raraku, Easter Island 11

$480 \pm 100$

Charcoal (Species 5) from a trench through mound of debris at foot of volcano Rano Raraku ( $27^{\circ} 10^{\prime} \mathrm{S}$ Lat, $109^{\circ} 20^{\prime} \mathrm{W}$ Long), Easter Island. The mound is believed to consist of stone refuse from the carving of the large stone statues. Sample was taken from a small charcoal layer $(0.3-0.5 \mathrm{~cm}$ deep) at top of mound. It dates the upper layers of debris in the mound, and thereby a time when activity in the quarries was at its height (Smith, 1961). Coll. 1955 by A. Skjölsvold, Stavanger Mus.; subm. by Thor Heyerdahl. (Age A.D. $1470 \pm$ $100)$.

\section{K-521. Rano Raraku, Easter Island}

1000 to 500

Earth lumps with small charcoal flakes from trench through mound of debris at foot of volcano Rano Raraku (27 $10^{\prime} \mathrm{S}$ Lat, $109^{\circ} 20^{\prime} \mathrm{W}$ Long), Easter Island. Sample taken from $3 \mathrm{~m}$ below top of mound. Dates the lowest layers in the mound of debris (Smith, 1961). Coll. 1955 by A. Skjölsvold; subm. by Thor Heyerdahl (Age A.D. 950 to 1450). Comment: sample was very impure; the small amount of charcoal that could be separated from the earth lumps was insufficient for normal treatment with acid. Date is therefore considered more uncertain than normal dates and is only given as the probable time interval.

\section{K-508. Rano Raraku, Easter Island 12}

$$
110 \pm 100
$$

Charcoal (Species 5) from layer at depth of $40 \mathrm{~cm}$ at left side of Statue 280 at Rano Raraku (27 $10^{\prime} \mathrm{S}$ Lat, $109^{\circ} 20^{\prime} \mathrm{W}$ Long), Easter Island. The layer was covered by a circular stone-packing (earth oven or umu). Sample dates the umu, and tells how close to our time the statue has been worshipped (Smith, 1961). Coll. 1955 by A. Skjölsvold; subm. by Thor Heyerdahl. (Age A.D. $1840 \pm 100)$.

\section{Orongo Village series, Easter Island}

Charcoal from a refuse trench at Orongo Village $\left(27^{\circ} 8^{\prime} \mathrm{S}\right.$ Lat, $109^{\circ} 26^{\prime}$ W Long), Easter Island. Samples date phases of the construction of Orongo Village (Smith, 1961). Coll. 1955 by E. N. Ferdon, Jr.; subm. by Thor Heyerdahl.

K-506. Orongo Village, Easter Island 3

$$
220 \pm 100
$$

Charcoal (Species 8) from Level 1, Horizon A. (Age A.D. $1730 \pm 100$ )

$$
\text { K-514. Orongo Village, Easter Island 4 } \quad 380 \pm 100
$$

Charcoal (Species 8) from Level 1, Horizon B. (Age A.D. $1570 \pm 100$ ) 
K-520. Orongo Village, Easter Island 5

Charcoal (Species 5) from Level 2. (Age A.D. 1410 \pm 100 )

K-522. Anakena, Easter Island 10

$430 \pm 100$

Charcoal (Species 5) from habitation layer at the hills W of Anakena Bay $\left(27^{\circ} 9^{\prime} \mathrm{S}\right.$ Lat, $109^{\circ} 25^{\prime} \mathrm{W}$ Long), Easter Island. From a habitation site inside a circular stone enclosure in front of a small cave. Sample came from bottom of a fireplace in the middle of the site, and was covered by stone slabs. Dates the time of habitation (Smith, 1961). Coll. by A. Skjölsvold; subm. by Thor Heyerdahl. (Age A.D. $1520 \pm 100$ )

\section{K-523. Ahu Vinapu, Easter Island 8}

$440 \pm 100$

Charcoal (Species 5) from a fire in surface of first ramp at back of Ahu I, Vinapu $\left(27^{\circ} 9^{\prime} \mathrm{S}\right.$ Lat, $109^{\circ} 20^{\prime} \mathrm{W}$ Long), Easter Island. Stratigraphically at junction between first and second occupation. Supplies date between first and second building period at ahu (Smith, 1961). Coll. 1955 by William Mulloy, Univ. of Wyoming; subm. by Thor Heyerdahl. (Age A.D. $1510 \pm$ 100)

K-509. Taipi, Marquesas Island

$440 \pm 100$

Charcoal (Species 10) from "Paeka", Taipi (ca. 9० 40' S Lat, $140^{\circ} \mathrm{W}$ Long), Nukuhiva, Marquesas Islands. Thin deposit of charcoal presumably lying on original surface and extending underneath Statue S-8 as well as a short distance in front of it. Overlain by naturally deposited soil ca. 10-15 cm thick. Dates erection of Statue S-8 and construction of Structure 3 (Smith, in press). Coll. by William Mulloy; subm. by Thor Heyerdahl. (Age A.D. 1510 $\pm 100)$

\section{K-525. Iipona marae, Marquesas Islands}

$640 \pm 100$

Charcoal (Species 11) from Iipona marae, Paumau Valley (ca. $9^{\circ} 40^{\prime} \mathrm{S}$ Lat, $139^{\circ} \mathrm{W}$ Long), Hiva Oa, Marquesas Islands. From a trench through Terrace 15 in front of great stone statue. Sample was taken from a charcoal layer at depth 1.1.1.3 $\mathrm{m}$ in the stone fill of the terrace. Base of the terrace occurs at a depth of $1.6 \mathrm{~m}$. Dates beginning of construction of this marae, upon which stands the greatest statue of the site (Smith, in press). Coll. 1955 by A. Skjöldsvold; subm. by Thor Heyerdahl. (Age A.D. $1310 \pm 100$ )

Date lists:

\section{ReFERENCES}

Copenhagen III Tauber, 1960a

Copenhagen IV Tauber, $1960 \mathrm{~b}$

Groningen II de Vries, Barendsen, and Waterbolk, 1958

Pennsylvania IV Ralph and Ackerman, 1961

Anonymous, 1959, in Notes and News: Am. Antiquity, v. 25, no. 1, p. 145-146.

Barghoorn, E. S., 1948, Sodium chlorite as an aid in paleobotanical and anatomical study of plant tissues: Science, v. 107, p. 480-481.

Fnglert, P. S., 1948, La Tierra de Hotu Matua: Santiago, Chile.

Glob, P. V., 1951, Ard and Plough: Aarhus, Denmark, p. 71-73 and p. 121-122.

Jessen, Knud, 1936, in Steensberg, Axel, En Muldfjœlsplov fra f $\varnothing$ rromersk Jernalder: Nord. Oldkyndighed of Historie, Aarbøger, p. 132-134.

Kapel, Holger, 1959, En uforstyrret stenalderboplads ved Draved: Sønderjysk Månedsskrift, v. 35, no. 8 , p. 161-165. 
Krog, Harald, 1960, Post-Glacial submergence of the Great Belt dated by pollen analysis and radiocarbon: Internatl. Geol. Cong., 21st, Copenhagen 1960, Rept., pt. 4, p. 127. 133.

Larsen, Helge, 1951, De dansk-amerikanske Alaska ekspeditioner 1949-1950: Geografisk Tidskrift [Copenhagen], v. 51, p. 63-93.

Olson, E. A., and Broecker, W. S., 1958, Sample contamination and reliability of radiocarbon dates: New York Acad. Sci. Trans., ser. 2, v. 20, p. 593-604.

Ralph, E. K., and Ackerman, R. K., 1961, University of Pennsylvania radiocarbon dates IV: Radiocarbon, v. 3, p. 4-14.

Smith, C. S., 1961, Radiocarbon dates from Easter Island (Heyerdahl, Thor, and Ferdon, Edwin N., Jr., Ed.), Norwegian Archaeol. Exped. to Easter Island and the East Pacific, Rept. 17, v. 1: Archaeol. of Easter Island, School of Amer. Res. and the Mus. of New Mexico, Mon. no. 24, pt. 1, p. 393-396.

Norwe in press, Radiocarbon dates from Rapa Iti, Raivavae, and the Marquesas: Norwegian Archaeol. Exped. to Easter Island and the East Pacific, Rept., v. 2.

Srodon, Andrzej, in press, Palaeobotany and startigraphy of the Late Pleistocene deposits in the northern Carpatians: INQUA Cong., 6th, Warsaw 1961, Paper.

Steensberg, Axel, 1936, North-west European plough-types of prehistoric times and the middle ages: Acta Archaeol., v. 7, p. 244-280.

in press, Recent finds of Danish prehistoric ploughing implements: Cong. of Anthropol. and Ethnol. Sci., 6th, Paris 1960, Paper.

Tauber, Henrik, 1960a, Copenhagen natural radiocarbon measurements III, corrections to radiocarbon dates made with the solid carbon technique: Am. Jour. Sci. Radioc. Supp., v. 2 , p. $5-11$ p. $12-25$.

1960b, Copenhagen radiocarbon dates IV: Am. Jour. Sci. Radioc. Supp., v. 2,

Vries, HI. de, Barendsen, G. W., and Waterbolk, H. T., 1958, Groningen radiocarbon dates II: Science, v. 127, p. 129-137.

Wasylikowa, Krystyna, in press, Pollen analysis of the Late Glacial sediments in Witow near Leczyca, Central Poland: INQUA Cong., 6th, Warsaw 1961, Paper. 